\title{
KAJIAN KEBIJAKAN PENGEMBANGAN USAHA BUDIDAYA PERIKANAN PADA LAHAN BEKAS GALIAN TAMBANG TIMAH DI PROPINSI KEPULAUAN BANGKA BELITUNG
}

\author{
Tajerin, Manadiyanto dan Sapto Adi Pranowo*)
}

\begin{abstract}
ABSTRAK
Potensi lahan bekas galian tambang timah yang sangat luas di Propinsi Kepulauan Bangka Belitung belum termanfaatkan secara optimal. Salah satu upaya pemanfaatan yang dipandang dapat meningkatkan kesejahteraan masyarakat secara luas adalah melalui pengembangan usaha budidaya perikanan. Penelitian yang bertujuan menentukan kebijakan yang tepat bagi pengembangan usaha budidaya perikanan pada lahan bekas galian tambang timah di Propinsi Kepulauan Bangka Belitung telah dilakukan sejak Januari-Desember 2004 dengan menggunakan pendekatan Analytic Hierarchy Process (AHP) menggunakan model analisis manfaat biaya. Berdasarkan kriteria aspek teknis, sosial dan ekonomi, hasil analisis menunjukkan bahwa terdapat dua kebijakan yang layak untuk dikembangkan, yaitu kebijakan pengembangan kapasitas kelembagaan dan kebijakan peningkatan dan perluasan pasar. Pengembangan kedua kebijakan tersebut harus memberikan manfaat terbesar bagi kesejahteraan masyarakat di wilayah desa dengan melibatkan peran utama dari pengusaha sebagai pelaku ekonomi serta mengedepankan upaya penciptaan transfer teknologi, kebanggaan sosial dan pendapatan daerah.
\end{abstract}

\section{ABSTRACT: Assessment of policy options for fish culture development on ex-tin mining land at Kepulauan Bangka Belitung Province. By: Tajerin, Manadiyanto and Sapto Adi Pranowo}

The potency of ex-tin mining land at Kepulauan Bangka Belitung Province had not been optimazed yet. One of optimization ways that generally could increase society welfare was through fish culture development. The research aimed at obtaining the appropriate policy options for fish culture development on ex-tin mining land at Kepulauan Bangka Belitung Province had conducted during January to December 2004 using an Analytical Bangka Belitung (AHP) approach with cost-benefit analysis model. The results showed that based on technical, social and economical criterias, two policy options could be developed : institutional capacity development policy and improvement and expansion of marketing policy. Development is those policy options have to serve the greatest social walfare benefit for locality with involving enterpreneur as an economic actor, and putting in the front of technologycal transfer, social dignity and regional income.

\section{KEYWORDS: ex-tin mining land, fisheries culture}

\section{PENDAHULUAN}

Pada saat ini pemerintah daerah Propinsi Kepulauan Bangka Belitung telah menetapkan sektor kelautan dan perikanan sebagai sumber pertumbuhan ekonomi unggulan. Dengan ditetapkannya kebijakan baru pembangunan tersebut, Dinas Kelautan dan Perikanan merupakan ujung tombak pelaksanaan kebijakan-kebijakan Pemerintah Daerah yang telah dirumuskan dalam Rencana Strategis Daerah dan dijabarkan dalam konsep perencanaan dan pelaksanaan yang melibatkan banyak pihak agar sektor Kelautan dan Perikanan di Propinsi Kepulauan Bangka Belitung dapat memacu sekaligus menjadi katalisator pertumbuhan ekonomi sektor-sektor pembangunan lainnya.
Salah satu potensi sumberdaya alam yang spesifik bagi sumber pertumbuhan baru melalui peran sektor kelautan dan perikanan di Propinsi Kepulauan Bangka Belitung adalah berupa lahan bekas kegiatan ekploitasi penambangan timah yang terlantar dalam luasan yang besar dan dengan jumlah yang banyak serta tersebar di banyak lokasi pada beberapa kawasan. Pada sisi lain, lahan bekas galian tambang timah yang terlantar tersebut bila tidak dimanfaatkan akan menimbulkan dampak negatif karena dapat mengganggu ekosistem dan lingkungan hidup masyarakat di sekitarnya.

Propinsi Kepulauan Bangka Belitung memiliki lahan bekas galian tambang timah (kolong) dengan luas areal 1.643 ha yang dinilai layak untuk dimanfaatkan sebagai areal perairan bagi kegiatan budidaya

\footnotetext{
- Peneliti pada Pusat Riset Pengolahan Produk dan Sosial Ekonomi Kelautan dan Perikanan
} 
perikanan (PKSPL, 2002; Dinas Perikanan Provinsi Kepulauan Bangka Belitung, 2003). Upaya pemanfaatan lahan bekas galian tambang timah (kolong) melalui pengembangan usaha budidaya perikanan di Propinsi Kepulauan Bangka Belitung telah mulai dikembangkan oleh Dinas Kelautan dan Perikanan setempat pada skala komersial dan telah pula dikembangkan oleh masyarakat sekitar kolong di bawah binaan dari perusahaan penambangan timah (PT. Kobatin). Hasil penelitian Wardoyo et al. (2003), untuk kasus bekas galian tambang pasir (situ), menunjukkan bahwa pemanfaatan perairan bekas galian tambang melalui kegiatan usaha budidaya perikanan, secara teknis dinilai layak dan akan memberikan produktivitas yang tinggi bila dilakukan menggunakan pendekatan "aquaculture based fisheries management". Demikian juga untuk kasus lahan bekas galian tambang timah (kolong), penelitian PKSPL (2002) di wilayah Propinsi Kepulauan Bangka Belitung dengan memperhatikan parameter kualitas air dan kandungan logam berat, menunjukan bahwa lahan bekas galian tambang timah dinilai layak untuk usaha budidaya perikanan (kolong yang telah berusia lebih dari 13 tahun). Hal tersebut disebabkan karena pada usia tersebut unsur-unsur logam dan kimia seperti $\mathrm{Hg}$, $\mathrm{Sn}$ dan $\mathrm{Fe}$ sudah tidak lagi terlarut, sedangkan mikroorganisme telah berkembang sebagai pakan alami bagi ikan.

Dukungan kebijakan pemanfaatan lahan bekas galian tambang timah khususnya untuk pengembangan usaha budidaya perikanan telah dilakukan oleh Pemerintah setempat, namun hingga saat ini belum ada kebijakan yang secara spesifik ditujukan bagi upaya pengembangan usaha budidaya perikanan pada lahan bekas galian tambang timah. Untuk itu, perlu dilakukan kajian secara holistik untuk menentukan opsi/alternatif kebijakan bagi pengembangan usaha budidaya perikanan pada lahan bekas galian tambang timah. Hasil penelitian ini diharapkan dapat bermanfaat sebagai bahan masukan dalam pengambilan keputusan tentang pengembangan usaha budidaya perikanan pada lahan bekas galian tambang timah di daerah penelitian.

\section{METODE}

\section{Lokasi dan Waktu Penelitian}

Penelitian ini merupakan studi kasus di wilayah propinsi Kepulauan Bangka Belitung yang memiliki kegiatan usaha budidaya perikanan di lokasi bekas galian tambang timah. Kegiatan penelitian dilakukan dalam dua tahap. Pada tahap pertama dilakukan pengamatan secara langsung kondisi lahan bekas galian tambang timah, dinamika masyarakat sekitar lahan bekas galian tambang timah, kondisi sosial, ekonomi dan budaya, lingkungan dan faktor lain yang dianggap berkaitan dengan upaya pemanfaatan lahan bekas galian tambang timah. Pada tahap ini dilakukan pengumpulan data sekunder yang berkaitan dengan topik penelitian, antara lain data mengenai potensi dan pemanfaatan lahan bekas galian tambang timah, data perkembangan usaha budidaya perikanan di lahan bekas galian tambang timah. Tahap pertama ini dilakukan pada bulan Mei hingga Agustus 2004. Pada tahap kedua, dilakukan pengambilan data primer dari responden yang dilaksanakan pada bulan September hingga November 2004

\section{Data dan Sumber Data}

Data yang dikumpulkan berupa data primer dan sekunder. Data primer diperoleh dari wawancara langsung dengan stakeholders berdasarkan panduan daftar pertanyaan yang ditujukan untuk mengetahui aspirasi dan persepsi mereka berkaitan dengan kriteria aspek kelayakan teknis, sosial dan ekonomi pengembangan usaha budaya perikanan pada lahan bekas galian tambang timah, dan mendapatkan alternatif kebijakannya. Responden dalam penelitian ini adalah mereka yang digolongkan sebagai orang yang ahli (expert) atau informan kunci berkaitan dengan topik permasalahan yang sedang di teliti. Para ahli atau informan kunci tersebut terdiri dari satu orang dari Dinas Perikanan dan Kelautan Kabupaten Bangka Tengah Propinsi Kepulauan Bangka Belitung, satu orang dari Dinas Kelautan dan Perikanan Propinsi Kepulauan Bangka Belitung, satu orang dari pihak perusahaan penambang timah milik swasta asing yang menjadi pembina dan perintis pengembangan usaha budidaya perikanan di lahan bekas galian tambang, satu orang dari Badan Perencanaan Pembangunan Daerah (Bappeda) Propinsi Kepulauan Bangka Belitung, satu orang dari pemerhati lahan bekas galian tambang dari kalangan Riset Kelautan dan Perikanan dan satu orang dari pembudidaya ikan yang dinilai dapat mewakili.

Data sekunder berupa laporan tahunan, laporan statistik dan laporan hasil penelitian yang diperoleh dari berbagai instansi terkait Dinas Kelautan dan Perikanan Propinsi dan Daerah, Kantor Kepala Desa, Kantor Statistik dan Bappeda serta publikasi laporan hasil penelitian dari lembaga-lembaga riset. Data sekunder yang dikumpulkan meliputi data kependudukan, keadaan geografis dan administratif, tata ruang pemanfaatan sumberdaya lahan, kebijakankebijakan mengenai pemanfaatan sumberdaya lahan konversi bekas galian timah, peta lokasi lahan bekas galian tambang timah serta laporan kondisi biofisik perairan di areal lahan konversi bekas galian tambang timah. 


\section{Metoda Analisis}

Kajian pengembangan usaha budidaya perikanan pada lahan bekas galian tambang timah di Propinsi Kepulauan Bangka Belitung, dilakukan dengan pendekatan Analytic Hierarchy Process (AHP) menggunakan model analisis rasio manfaat biaya. Penggunaan model analisis rasio manfaat biaya melalui pendekatan AHP berkaitan dengan pengelolaan dan pemanfaatan sumberdaya alam telah dilakukan oleh banyak peneliti di Indonesia, antara lain Tomboelu et al. (2000); Mustafa et al. (2003) dan Rifqi et al. (2003). Adapun tahapan analisisnya adalah sebagai berikut (Saaty, 1999): (1) Identifikasi sistem; (2) Penyusunan hierarki; (3) Komparasi berpasangan (Pairwaise Comparison); (4) Konsistensi dan akurasi; (5) Penyusunan matrik pendapat individu; (6) Penyusunan matrik pendapat gabungan; (7) Pengolahan horizontal; (8) Pengolahan vertikal; dan (9) Revisi pendapat (Permadi, 1992; Saaty, 1999).

Penggunaan AHP dengan model analisis rasio biaya manfaat dilakukan dengan memperhatikan beberapa hal berikut. Pada tahap awal penerapan AHP terlebih dahulu harus diperhatikan beberapa hal penting sebagai berikut (Saaty, 1999): (1) Memisahkan biaya dan manfaat; (2) Mengkuantifikasi faktor kualitatif; (3) Mengevaluasi sumberdaya dan aktivitas campuran; dan (4) Menstruktur hierarki manfaat dan biaya. Selanjutnya, setelah proses sintesa dari analisis AHP, dilakukan perhitungan nilai manfaat dan biaya dari masing-masing hierarki berdasarkan perbandingan manfaat dengan biaya Kriteria yang digunakan adalah:

$\mathrm{B} / \mathrm{C}<1$, menunjukkan alternatif kebijakan yang layak dipilih dalam pengembangan usaha budidaya perikanan pada lahan bekas galian tambang timah di Propinsi Kepulauan Bangka Belitung

$\mathrm{B} / \mathrm{C}<1$, menunjukkan alternatif kebijakan yang tidak layak dipilih dalam pengembangan usaha budidaya perikanan pada lahan bekas galian tambang timah di Propinsi Kepulauan Bangka Belitung

\section{HASIL DAN BAHASAN}

\section{Kondisi Umum Lahan Bekas Galian Tambang Timah di Propinsi Kepulauan Bangka Belitung}

Lahan bekas galian tambang timah meninggalkan cekungan di permukaan tanah yang cukup luas dan dengan kedalaman berkisar antara satu hingga puluhan meter, yang kemudian terisi air hujan, air sungai atau air laut. Lahan bekas galian tambang timah yang berisi air tersebut oleh masyarakat di
Propinsi Kepulauan Bangka Belitung disebut dengan nama "kolong". Dalam rangka pemberdayaan masyarakat serta peningkatan ekonomi masyarakat desa sebagai sentra produksi perikanan darat, maka perlu memanfaatkan potensi kolong yang tersedia. Kolong-kolong bekas galian tambang timah dari zaman Belanda diperkirakan sejak 200 tahun yang lalu dibiarkan saja tanpa program pengembangan yang jelas dan berkelanjutan dengan indikasi periaran kolong masih didominasi ikan-ikan lokal seperti ikan tanah, kemuring, betok, sepat, belida dan lain-lain (Dinas Kelautan dan Perikanan Propinsi Kepulauan Bangka Belitung, 2003)

Melihat jenis-jenis ikannya yang ditemukan dari perairan kolong, pada umumnya kolong-kolong tersebut mempunyai prospek yang baik untuk pengusahaan perikanan. Pertumbuhan biota nabati dipengaruhi oleh umur dan kedalaman kolong. Semakin tua umur kolong semakin banyak jenis dan jumlahnya dan semakin banyak ditumbuhi jenis-jenis biota yang bersifat sub merge (tenggelam) maupun merge (muncul). Jenis dan jumlah biota nabati pada tingkatan tertentu sangat berguna bagi ikan terutama sebagai media reproduksi, perlindungan maupun pakan alami (PKSPL, 2002). Selanjutnya dikemukakan bahwa agar usaha tersebut dapat berkelanjutan perlu diperhatikan beberapa aspek penting seperti aspek teknis maupun non teknis dari lahan bekas galian tambang timah tersebut.

\section{Aspek teknis (Aspek fisika dan kimia)}

Secara umum, untuk lahan bekas galian tambang timah dengan umur rata-rata di bawah 13 tahun, parameter kualitas air menunjukan bahwa berdasarkan kejernihan kolong-kolong tersebut dikategorikan kurang subur dengan transparansi rata-rata di atas 1 meter yang menunjukkan miskin unsur hara. Demikian juga angka pH air umumnya rendah yang erat kaitannya dengan kekhasan keasaman air di Pulau Bangka dan Pulau Belitung. Kandungan pH yang rendah akan sangat menghambat pertumbuhan ikan, apalagi aklimatisasinya juga rendah, karena alkalinitas (kandungan bikarbonat) penting sebagai buffer keasaman. Hasil penelitian PKSPL (2002) menujukkan bahwa beberapa indikator parameter kualitas air sebagai syarat yang ideal untuk kegiatan usaha budidaya perikanan di kolong tertera pada Tabel 1 .

\section{Aspek non teknis}

Aspek non teknis tidak kalah pentingnya dan merupakan faktor penunjang keberhasilan kegiatan budidaya ikan yang akan dan sedang dilaksanakan. Beberapa hal yang perlu diperhatikan adalah: (1) 
Tabel 1. Kualitas air kolong usia di atas 13 tahun di Propinsi Kepulauan Bangka Belitung

Table 1. Water quality of kolong above 13 years old in Kepulauan Bangka Belitung Province

\begin{tabular}{lc}
\hline \multicolumn{1}{c}{$\begin{array}{c}\text { Parameter kualitas air/ } \\
\text { Water quality parameters }\end{array}$} & $\begin{array}{c}\text { Tingkat optimum/ } \\
\text { Optimum level }\end{array}$ \\
\hline 1. Suhu air/Water temperature & $25-30^{\circ} \mathrm{C}$ \\
2. Kecerahan/Lighting & $42-45^{\circ} \mathrm{C}$ \\
3. Alkalinitas/Alcalinity & $20-150 \mathrm{mg} / \mathrm{l}$ \\
4. $\mathrm{CO}_{2}$ & $<5 \mathrm{mg} / \mathrm{l}$ \\
5. $\mathrm{O}_{2}$ & $>5 \mathrm{mg} / \mathrm{l}$ \\
6. $\mathrm{pH}$ & $6.5-8$ \\
7. $\mathrm{NH}_{3}$ & $<0.6 \mathrm{mg} / \mathrm{l}$ \\
8. $\mathrm{H}_{2} \mathrm{~S}$ & $<1 \mathrm{mg} / \mathrm{l}$ \\
\hline
\end{tabular}

Sumber/Source: PKSPL (2002)

Tingkat pengamanan usaha baik hama binatang maupun pencurian oleh manusia; (2) Letak lokasi kegiatan yang meliputi akses transportasi dan kemudahan jangkauan; dan (3) Aspek pemasaran dan distribusi hasil.

Menurut pandangan para responden, keunggulan kegiatan usaha budidaya ikan di kolong dengan sistem karamba jaring apung (KJA) dibandingkan dengan sistem kolam dan lainnya, antara lain: (1) Tidak memerlukan pengolahan lahan; (2) Mudah dalam pengawasan dan pengendalian seperti saat hujan atau banjir; (3) Ekosistem kolong umumnya stabil/homogen dengan lingkungan sekitar; (4) Mudah dalam pemanenan dan pemisahaan ukuran; dan (5) Lebih ekonomis dan murah dibandingkan dengan sistem kolam.

\section{Potensi Lahan Bekas Galian Tambang Timah (Kolong) di Propinsi Kepulauan Bangka Belitung}

Dari Tabel 2 diketahui bahwa lahan bekas galian tambang timah (kolong) di Propinsi Kepulauan Bangka Belitung yang potensial untuk dimanfaatkan sebagai lahan (perairan) usaha budidaya perikanan menggunakan sistem karamba jaring apung (KJA) seluruhnya seluas 1.463 hektar yang meliputi 1.045 buah kolong yang tersebar di dua buah pulau (Pulau Bangka dan Pulau Belitung). Untuk Pulau Bangka, lahan bekas galian tambang timah (kolong) seluas 824,6 hektar $(56,36 \%)$ dengan 589 buah kolong yang tersebar di sembilan wilayah kecamatan dalam 4 daerah kabupaten. Sedangkan untuk Pulau Belitung lahan kolong tersebut seluas 638,4 hektar $(43,64 \%)$ dengan 456 buah kolong yang tersebar di sembilan wilayah kecamatan dalam dua daerah kabupaten.

\section{Pemanfaatan Lahan Bekas Galian Tambang Timah (Kolong) Di Propinsi Kepulauan Bangka Belitung}

Hingga saat ini pemanfaatan lahan bekas galian tambang timah (kolong) di Propinsi Kepulauan Bangka Belitung telah dilakukan untuk keperluan usaha non perikanan, usaha budidaya perikanan dan restocking. Pemanfaatan kolong untuk jenis kegiatan non perikanan seperti perusahaan air minum (PDAM), perusahaan tenaga listrik dan wisata masih tergolong sangat rendah, yaitu baru mencapai $0,044 \%$ dari total potensi kolong atau seluas $64,37 \mathrm{ha}$. Demikian juga untuk pemanfaatan usaha budidaya perikanan, seperti untuk sentra pembenihan ikan, budidaya labilabi dan budidaya pembesaran ikan nila merah dalam sistem karamba jaring apung (KJA) baru mencapai luasan $0,029 \%$ dari total potensi kolong atau seluas 42,43 ha (Juhar, 2000; Dinas Kelutan dan Perikanan Propinsi Kepulauan Bangka Belitung, 2003). Sedangkan areal lahan kolong yang digunakan sebagai lokasi perairan untuk restocking ikan baru mencapai luasan $0,012 \%$ dari total potensi kolong atau seluas 17,56 ha (Dinas Kelautan dan Perikanan Propinsi Bangka Belitung, 2003).

Ditinjau dari bentuk pengelolaan pemanfaatan kolong, dikenal 2 buah bentuk pengelolaan, yaitu pengelolaan oleh pengusaha dan secara bersama (masyarakat, pengusaha dan pemerintah). Beberapa aspek internal dan eksternal berkaitan dengan bentuk pengelolaan tersebut di atas dapat diuraikan sebagai berikut.

Secara internal terdapat kekuatan seperti telah tersedianya Peraturan Daerah Nomor 10 Tahun 2002 tentang pengelolaan dan pemanfaatan kolong, potensi sumberdaya alam kolong yang cukup banyak dan 
Tabel 2. Distribusi Kolong berusia lebih dari 13 tahun di Propinsi Kepulauan Bangka Belitung, 2002

Table 2. Distribution of "Kolong" above 13 years in Kepulauan Bangka Belitung Province

\begin{tabular}{|c|c|c|c|}
\hline $\begin{array}{c}\text { Kabupaten (Kecamatan)/ } \\
\text { District (Sub District) }\end{array}$ & $\begin{array}{l}\text { Buah/ } \\
\text { No. of } \\
\text { "Kolong" }\end{array}$ & $\begin{array}{c}\text { Luas } \\
\text { Iahan/Area } \\
\text { (Ha) }\end{array}$ & $\begin{array}{c}\text { Persentase luas } \\
\text { Iahan/Percentage of } \\
\text { area }(\%)\end{array}$ \\
\hline \multicolumn{4}{|l|}{$\begin{array}{l}\text { A. Pulau Bangka/ } \\
\text { Bangka Island }\end{array}$} \\
\hline $\begin{array}{l}\text { - Kabupaten Bangka/ } \\
\text { Bangka District }\end{array}$ & 208 & 291.2 & 19.9 \\
\hline $\begin{array}{l}\text { - Kabupaten Bangka Barat/ } \\
\text { West Bangka District }\end{array}$ & 120 & 182 & 12.45 \\
\hline $\begin{array}{l}\text { - Kabupaten Bangka Tengah/ } \\
\text { Central Bangka District }\end{array}$ & 212 & 282.8 & 19.33 \\
\hline $\begin{array}{l}\text { - Kabupaten Bangka Selatan/ } \\
\text { South Bangka District }\end{array}$ & 49 & 68.6 & 4.68 \\
\hline \multicolumn{4}{|l|}{$\begin{array}{l}\text { B. Pulau Belitung/ } \\
\text { Belitung /sland }\end{array}$} \\
\hline $\begin{array}{l}\text { - Kabupaten Belitung/ } \\
\text { Belitung District }\end{array}$ & 262 & 366.8 & 24.38 \\
\hline $\begin{array}{l}\text { - Kabupaten Belitung Timur/ } \\
\text { East Belitung District }\end{array}$ & 194 & 271.6 & 18.57 \\
\hline Total $(A+B)$ & 1.045 & 1.463 & 100 \\
\hline
\end{tabular}

Sumber/Source: Diolah dari Data Statistik Dinas Perikanan Propinsi Kepulauan Bangka Belitung (2003)/Calculated from Data of the Fisheries Statistics Official of Kepulauan Bangka Belitung Province (2003)

tersebar, adanya sebagian masyarakat yang berdomisili di sekitar kolong, serta uji coba teknologi budidaya ikan air tawar di kolong dengan karamba jaring apung yang ternyata cukup berhasil. Hasil analisis usaha dari uji coba tersebut dapat dilihat pada sub bagian berikutnya.

Di sisi lain secara internal terdapat kelemahankelemahan, seperti belum dikuasainya teknologi budidaya ikan dalam karamba jaring apung oleh sebagian besar masyarakat, terbatasnya akses model kerja masyarakat di sekitar kolong, dan belum diketahui secara tepat letak lokasi kolong yang dinilai layak dan data-data atau informasi kondisi teknis dan biofisik secara lengkap dari kolong-kolong yang ada seperti mengenai luasan, kedalaman, $\mathrm{pH}$, usia dan sebagainya.

Secara eksternal terdapat peluang pasar yang cukup baik untuk pemasaran ikan air tawar konsumsi, adanya pengusaha swasta/investor yang akan mengelola dan mengembangkan kawasan kolong untuk budidaya ikan air tawar. Selain adanya peluang, terdapat ancaman dan tantangan yang harus dihadapi, yaitu dikhawatirkan adanya masyarakat yang melakukan penangkapan ikan di kolong dengan menggunakan putas atau bom ikan di kawasan kolong restocking serta sering berkembangnya kegiatan penambangan konvesional yang ilegal.

Berdasarkan pertimbangan faktor eksternal dan internal tersebut maka orientasi perencanaan pengelolaan dan pemanfaatan kolong harus diupayakan pada arah peningkatan hasil dan pencapaian sasaran, pelaksanaan operasional yang tepat, efektif dan efisien yang dilakukan secara bertahap dan berkelanjutan

\section{Usaha Pembesaran Ikan Air Tawar Secara Intensif dalam Karamba Jaring Apung di Kolong}

Pembuatan karamba jaring apung (KJA) menggunakan bahan konstruksi berupa kayu, baik kayu balok $6 / 8 \mathrm{~cm}$ maupun bulat dengan diameter 6 $10 \mathrm{~cm}$, kayu bulat dengan panjang berkisar 8 meter dirancang untuk 1 unit karamba sebanyak 4 petak tanpa sambungan. Kayu tersebut dirangkai menyerupai tangga dengan jarak antar kayu kurang lebih $40 \mathrm{~cm}$ menggunakan kayu alang berupa balok 
Tabel3. Analisis usaha pembesaran ikan nila merah dalam karamba jaring apung di Perairan Kolong, Kabupaten Bangka ( $\mathrm{N}=12$ responden)

Table 3. An analysis of red thilapia fish culture in floating net cages in "Kolong" Waters, Bangka District ( $N=12$ respondent)

Uraian/Descriptions

A. Modal awal (Investasi)/ Intial capital (Investment)

1 Pembuatan Rakit Karamba/Net Cages Construction

a. Kayu bulat/Cylinder Wood $\varnothing 6-10 \mathrm{~cm}, \mathrm{p}=8 \mathrm{~m} ; 12 \mathrm{bh}$

b. Kayu kasau/Processing wood $4 / 6 \mathrm{~cm} ; 12$ btg

c. Papan lantai/Floor flate $\mathrm{t}=3 \mathrm{~cm}(2 \mathrm{brs}) ; 24 \mathrm{kpg}$

d. Drum plastik/Plastic drum vol. 200 l; 15 bh

e. Baut/bout 10"/ 7"; 50 btg

f. Paku/Nail 2", 3" dan 5"; $10 \mathrm{~kg}$

g. Tali pengikat drum/Drum tighting tile $0,5 \mathrm{~cm} ; 15 \mathrm{~kg}$

h. Upah pembuatan rakit/Wage of cage construction 1 unit

2 Pembuatan kantung jaring/Net construction

a. Jaring polyetilene/Polytheline net $\mathrm{ms} 10 \mathrm{~cm}$ dan $2 \mathrm{~cm} ; 4 \mathrm{bh}$

b. Waring/Netting $2 \times 2 \times 1,5 \mathrm{~m}^{3} ; 4 \mathrm{bh}$

c. Tali ris dan sudut/Rise tile and angle $10 \mathrm{~kg}$

d. Upah jahit tali ris/Wage of tailor to ristile $8 \mathrm{bh}$

3 Pembuatan pondok jaring apung/Floating net gazebo construction

a. Kayu tiang/Boplank wood $10 \mathrm{btg}$

b. Kayu penyanggah/Buffer wood 20 btg

c. Kayu reng atap/Ceiling wood $10 \mathrm{btg}$

d. Papan dinding $/ W$ all wood $2,5 \mathrm{~cm} ; 40 \mathrm{kpg}$

e. Atap/Ceiling 4 ikat

f. Paku/Nail 2" dan 3"; 5 kg

g. Drum pelampung/Drum vol. 200 l; 6 bh

h. Upah pembuatan pondok/Wage of gazebo construction 1unit

4 Sarana penunjang (petromak, senter, dan lain lain.)/Supporting facilties (lamp, etc.)

B. Biaya total/Total cost

1 Biaya tetap/Fixed cost

a. Penyusutan rakit karamba/Cage depreciation

b. Penyusutan kantong jaring/Netting depreciation

c. Penyusutan pondok jaring apung/Floating net gazebo depreciation

d. Penyusutan sarana penunjang/Supporting facility depreciation

2 Biaya variabel/Variable cost

a. Benih ikan nila merah/Red thilapia fish seed 4000 ekor

b. Pakan ikan/Fish feed

c. Tenaga kerja/Labor 1 org

d. Perawatan/Maintenance 6 bln

3 Biaya lain-lain/pajak usaha/Others cost $1,5 \%$ per cikles

C. Penerimaan total/Total revenue

- Produksi/Production $=4.000$ ekor $\times 0,8 \times 0,8 \mathrm{~kg} /$ ekor $=2.560 \mathrm{~kg}$

- Harga ikan nila merah/Price of red thilapia fish $=\mathrm{Rp} .11 .000,-/ \mathrm{kg}$.
Jumlah/Mount

(Rp.)

8.120.000,-

3.430.000,-

120.000,-

120.000,-

480.000,

1.500.000,-

350.000,-

60.000,-

300.000,-

500.000,-

2.200.000,-

1.000.000,-

600.000,-

200.000,-

400.000,-

1.990.000,-

100.000,-

160.000,-

50.000,-

600.000,-

200.000 -

30.000 -

600.000 ,-

250.000,-

500.000,-

22.684.800,-

1.624.000,-

686.000.-

440.000.-

398.000 -

100.000,-

20.600.000,

1.000.000,-

16.000.000 -

1.800.000,-

$1.800 .000,-$

460.800,

28.100.000,Rasio penerimaan/Biaya/Ratio of revenue/Cost (R/C ratio) 1,24

Sumber/Sources: Diolah dari data Primer pada Kelompok Usaha Bersama Binaan di Kecamatan Koba, Kabupaten Koba Tengah (2004)/Calculated from primary data of the Cooperation Farming Group in Koba Sub District, Central Koba District (2004) 
kasau 4/6 sebagai penyangga papan dengan jarak antar kasau 1 meter. Kemudian dirangkai membentuk empat persegi dengan panjang 8 meter. Kemudian dipasang alang tengah sehingga terbagi menjadi 4 petak dengan jarak dan luas bagian dalam 3,5 × 3,5 $\mathrm{m}^{2}$ sehingga membentuk 4 petak atau 1 unit karamba.

Pelampung yang digunakan berupa drum palstik kapasitas 200 liter sebanyak 15 buah per unit, sedangkan lantai alang berupa papan dengan tebal 3 $\mathrm{cm}$ sebanyak 24 keping per unit ukuran jaring yang digunakan sesuai dengan ukuran benih pada saat penebaran awal yaitu dengan ukuran benih per ekor 8-10 cm sebanyak 4.000 ekor dengan ukuran jaring $2 \times 2 \times 1,2 \mathrm{~m}^{3}$. Setelah 2 bulan ikan yang dipelihara dipisahkan menjadi 2.000 ekor dengan menggunakan jaring polyetilen yang berukuran mata jaring $2 \mathrm{~cm}$ dan 2 bulan berikutnya 1.000 ekor dengan waring $3 \times 3 \times 2,5$ $\mathrm{m}^{3}$.

Teknis pemberian pakan dengan sistem adlibitum (pemberian pakan disesuaikan dengan selera makan ikan) dengan tanda-tanda pada kondisi lapar ikan akan naik ke permukaan dan apabila telah kenyang aktifitasnya berkurang kemudian kembali ke dasar. Untuk ukuran benih awal sampai umur 2 bulan pemberian pakan diintensifkan sampai 5 kali sehari menggunakan pakan pellet yang disesuaikan dengan bukaan mulut ikan dengan waktu pemberian pakan berkisar jam 7.00; 10.00; 13.00; 15.00 dan 17.00 . Sedangkan untuk ukuran ikan yang berumur 2 sampai 4 bulan pada awal penebaran dapat diberikan 3 kali sehari, yaitu pagi, siang dan sore. Waktu pemberian pakan ikan dengan masa pemeliharaan 4-6 bulan dapat dilakukan pada pagi dan sore hari.

Keragaan usaha pembesaran ikan nila merah dalam karamba jaring apung di perairan kolong di Kabupaten Bangka Belitung adalah seperti tercantum pada Tabel 3.

\section{Analisis Kebijakan Pengembangan Budidaya Perikanan pada Lahan Bekas Galian Tambang Timah}

\section{Manfaat pengembangan budidaya perikanan}

Berdasarkan bobot prioritas penilaian responden, dari Gambar 3 (Lampiran 1) dapat diketahui bahwa manfaat pengembangan budidaya perikanan pada lahan bekas galian tambang timah di Propinsi Kepulauan Bangka Belitung, menurut para responden harus lebih banyak memberikan manfaatnya di tingkat desa (WDK) dengan bobot 0.56501 , selanjutnya tingkat kecamatan (WKT) dengan bobot 0.26220 , kabupaten (WKB) dengan bobot 0.11750 , dan terakhir pada tingkat propinsi (WPS) dengan bobot 0.05529 .
Untuk mewujudkan manfaat pengembangan budidaya perikanan pada lahan bekas galian tambang tersebut, diperlukan peran yang lebih besar dari pengusaha (PSH) dengan bobot 0.57900 dibandingkan peran masyarakat (MSK) dengan bobot 0.33461 dan peran pemerintah (PMT) dengan bobot 0.08640. Manfaat yang dirasakan tersebut lebih banyak bersifat manfaat dari kriteria teknik dan lingkungan (KTLK) dengan bobot 0.42564 , selanjutnya disusul oleh manfaat dari kriteria ekonomi (KEKN) dengan bobot 0.23629 dan terkahir manfaat dari kriteria sosial (KSSL) dengan bobot 0.08808 .

Usaha budidaya ikan pada lahan bekas galian tambang timah merupakan jenis usaha yang tergolong baru, tentunya masih memiliki kemungkinan resiko (risk) kegagalan dan ketidakpastian (uncertainty) usaha yang besar. Oleh karena itu, keberanian pengusaha menghadapi kemungkinan resiko (risk) dan ketidakpastian (uncertainty) tersebut lebih diharapkan dibanding dengan pelaku ekonomi lainnya (masyarakat dan pemerintah) dengan tetap memperhatikan pengalokasian sumberdaya secara lestari. Dengan perkataan lain, diharapkan para pengusaha dapat bersifat sebagai pengusaha yang risk lover.

Manfaat terbesar yang dapat diterima oleh para pelaku ekonomi dengan adanya kegiatan usaha budidaya perikanan tersebut, adalah manfaat yang bersumber dari aspek sosial berupa kebanggaan (KBG) dengan bobot 0.87497 dan manfaat terbesar kedua bersumber dari aspek teknik dan lingkungan berupa transfer teknologi (TTI) dengan bobot 0.83444 , selanjutnya disusul oleh manfaat aspek ekonomi berupa peningkatan pendapatan daerah (PPD) dengan bobot 0.63698 . Hasil analisis pada level selanjutnya sampai dengan mendapat alternatif kebijakan pengembangan budidaya perikanan pada lahan bekas galian tambang timah di Propinsi Kepulauan Bangka Belitung seperti tertera pada Tabel 4.

Dari Tabel 4 diketahui bahwa dari sisi manfaat, para responden memberikan bobot penilaian terbesar kepada kebijakan pengembangan kelembagaan usaha perikanan (KPKUP) dengan bobot 0.40301 , prioritas berikutnya secara berurutan adalah kebijakan peningkatan dan perluasan hasil perikanan (KPPHP) dengan bobot 0.28528 ; kebijakan peningkatan promosi investasi usaha perikanan (KPPUP) dengan bobot 0.15462 ; kebijakan pengembangan teknologi budidaya perikanan (KPTBP) dengan bobot 0.10416; dan kebijakan pengembangan infrastruktur usaha perikanan (KPIUP) dengan bobot 0.05293

\section{Biaya pengembangan budidaya perikanan}

Dari Gambar 4, dilihat berdasarkan bobot penilaian dari responden diketahui bahwa biaya dalam 


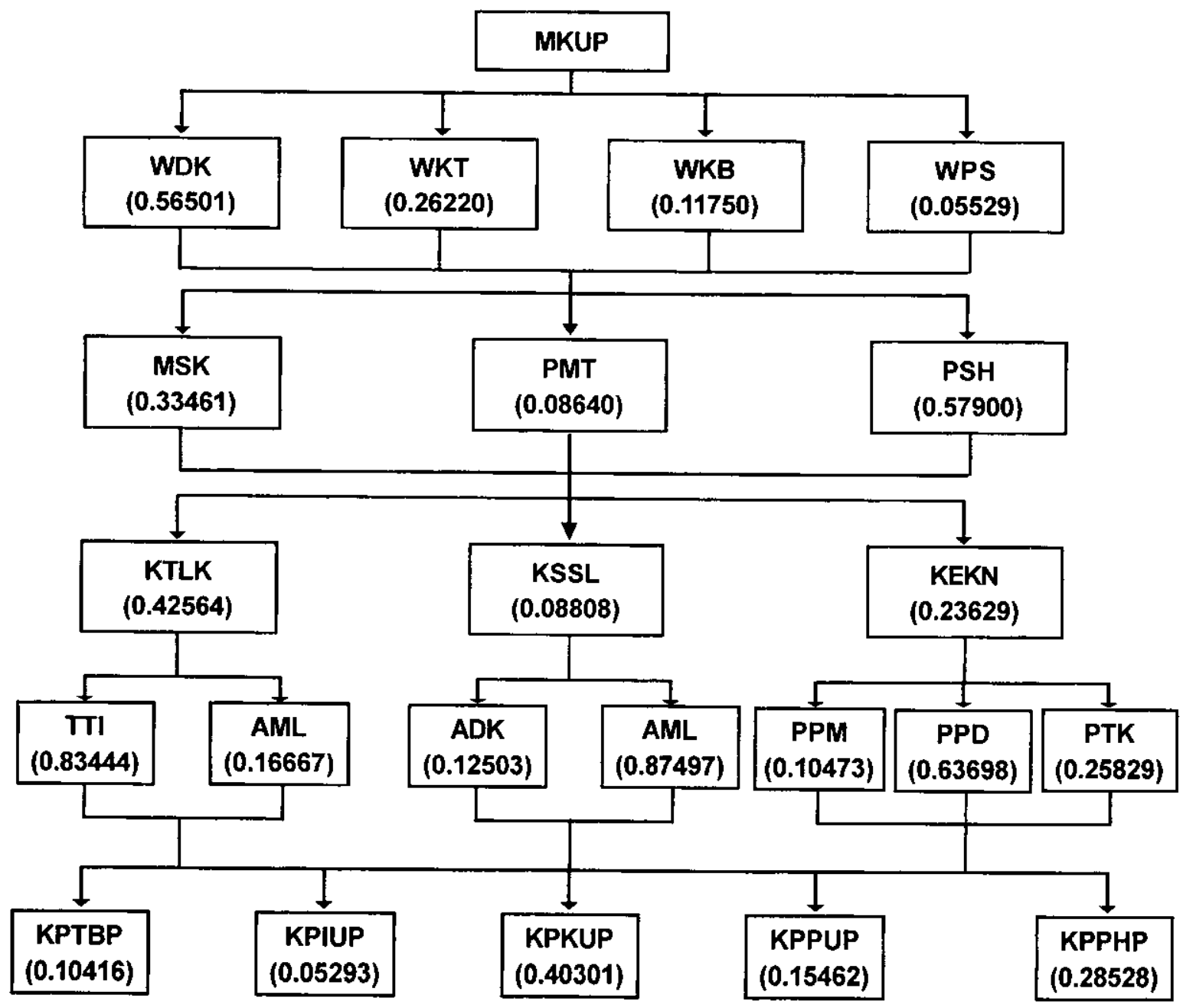

Gambar 3. Struktur hierarki manfaat pengembangan kolong untuk budidaya perikanan.

Figure 3. Hierarchy structure of benefit from kolong development for fish culture.

Keterangan: Angka dalam kurung merupakan bobot penilaian reponden dari hasil pengolahan data primer menggunakan AHP.

Remaks: Value in parenthesis as a weight of respondent judgement from result primary data calcutation using AHP.

Keterangan/Remaks:

MKUP = manfaat kolong untuk pengembangan budidaya perikanan/benefit of "kolong" for fisheries culture development

WDK = wilayah desa di mana kolong berada/rural area where "kolong" exiting

WKT = wilayah kecamatan di mana kolong berada/ sub district area where "kolong" exiting

WKB = wilayah kabupaten di mana kolong berada/district area where "kolong" exiting

WPS = wilayah propinsi di mana kolong berada/province area where "kolong" exiting

MSK = masyarakat/society

PMT = pemerintah/government

$\mathrm{PSH}=$ swasta atau perusahaan/private or enterpreneur

KTLK = kriteria teknik dan lingkungan/citerias of technological and enviromental

$\mathrm{KSSL}=\mathrm{kriteria}$ sosial/criteria of social

$\mathrm{KEKN}=$ kriteria ekonomi/criteria of economic

TII = transfer teknologi/technological transfer 


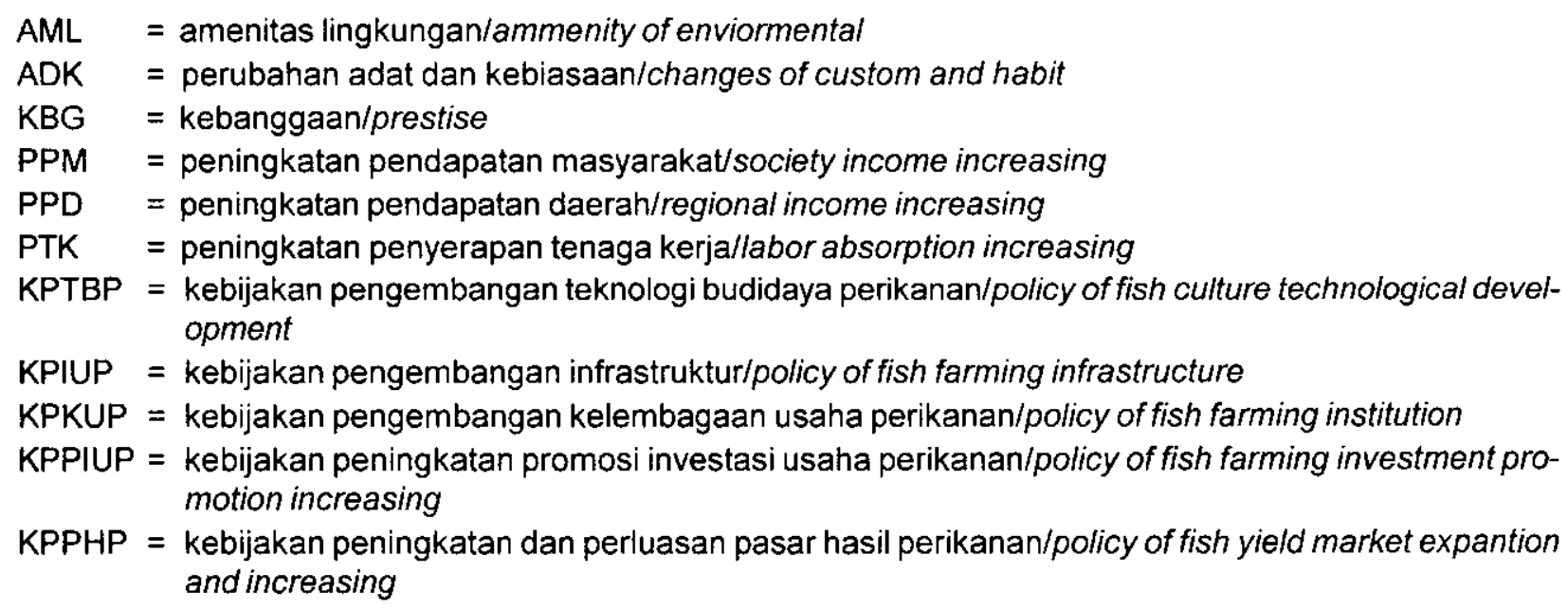

Tabel 4. Hasil analisis manfaat pengembangan usaha budidaya perikanan pada lahan bekas galian tambang timah di Propinsi Kepulauan Bangka Belitung

Table 4. Result of analysis of fish culture farming development benefit at receptacle land of tin exploitation in Kepulauan Bangka Belitung Province

\begin{tabular}{|c|c|c|c|c|c|c|c|c|c|c|}
\hline \multirow[t]{2}{*}{ No } & \multirow[t]{2}{*}{$\begin{array}{l}\text { Alternatif kebijakan' } \\
\text { Policy alternative }\end{array}$} & \multicolumn{2}{|c|}{$\begin{array}{c}\text { Teknik dan } \\
\text { lingkungan/Technical } \\
\text { and emvironmental }\end{array}$} & \multicolumn{2}{|c|}{ SosialSocial } & \multicolumn{3}{|c|}{ BkonomilEkonomic } & \multirow{2}{*}{$\begin{array}{l}\text { Rataan } \\
\text { bobot/ } \\
\text { Average } \\
\text { weight }\end{array}$} & \multirow[t]{2}{*}{$\begin{array}{l}\text { Prioritas } \\
\text { IPriorty }\end{array}$} \\
\hline & & $\pi$ & AML & ADK & KBG & PPM & PPD & PTK & & \\
\hline $\begin{array}{r}11 \\
1 \\
1\end{array}$ & $\begin{array}{l}\text { Kebijakan Pengembangan } \\
\text { Teknologi Budidaya } \\
\text { Perikanan/Policy of Fish } \\
\text { Culture Technological } \\
\text { Development (KPTBP) }\end{array}$ & 0.06819 & 0.06726 & 0.0973 & 0.1131 & 0.0911 & 0.1459 & 0.1463 & 0.10416 & 4 \\
\hline 2 & $\begin{array}{l}\text { Kebijakan Pengembangan } \\
\text { Infrastruktur/Policy of Fish } \\
\text { Farming Infrastucture } \\
\text { Development (KPIUP) }\end{array}$ & 0.04214 & 0.04828 & 0.0621 & 0.0428 & 0.0555 & 0.0597 & 0.0601 & 0.05293 & 5 \\
\hline 31 & $\begin{array}{l}\text { Kebijakan Pengembangan } \\
\text { Kelembagaan Usaha } \\
\text { Perikanan/Policy of Fish } \\
\text { Farming Institutional } \\
\text { Development (KPKUP) }\end{array}$ & 0.45506 & 0.45501 & 0.3455 & 0.4774 & 0.3662 & 0.3706 & 0.3513 & 0.40301 & 1 \\
\hline 4 & $\begin{array}{l}\text { Kebijakan Peningkatan } \\
\text { Promosi Investasi Usaha } \\
\text { Perikanan/Policy of Fish } \\
\text { Farming Investment } \\
\text { Promotion Increasing } \\
\text { (KPPIUP) }\end{array}$ & 0.2835 & 0.23262 & 0.1629 & 0.0725 & 0.1429 & 0.0942 & 0.0938 & 0.15462 & 3 \\
\hline 5 & $\begin{array}{l}\text { Kebijakan Peningkatan dan } \\
\text { Perluasan Pasar Hasil } \\
\text { Perikanan/Policy of Fish } \\
\text { Yield Market Expantion and } \\
\text { Increasing (KPPHP) }\end{array}$ & 0.15111 & 0.19683 & 0.3323 & 0.2943 & 0.3443 & 0.3296 & 0.3485 & 0.28528 & 2 \\
\hline
\end{tabular}

Sumber/Sources: Hasil pengolahan data primer menggunakan Analytic Hierarchy Process /Result of calculation from primary data using Analytic Hierarchy Process 
Keterangan/Remaks:

$\mathrm{TTI}=$ transfer teknologi/technolgical transfer

AML = amenitas lingkungan/environmental amenity

ADK = perubahan adat dan kebiasaan/changes on custome and habit

$\mathrm{KBG}=$ kebanggaan/prestise

PPM = peningkatan pendapatan masyarakat/increasing on society income

$\mathrm{PPD}=$ peningkatan pendapatan daerah/increasing on regional income

PTK = peningkatan penyerapan tenaga kerja/increasing on employment absorbtion

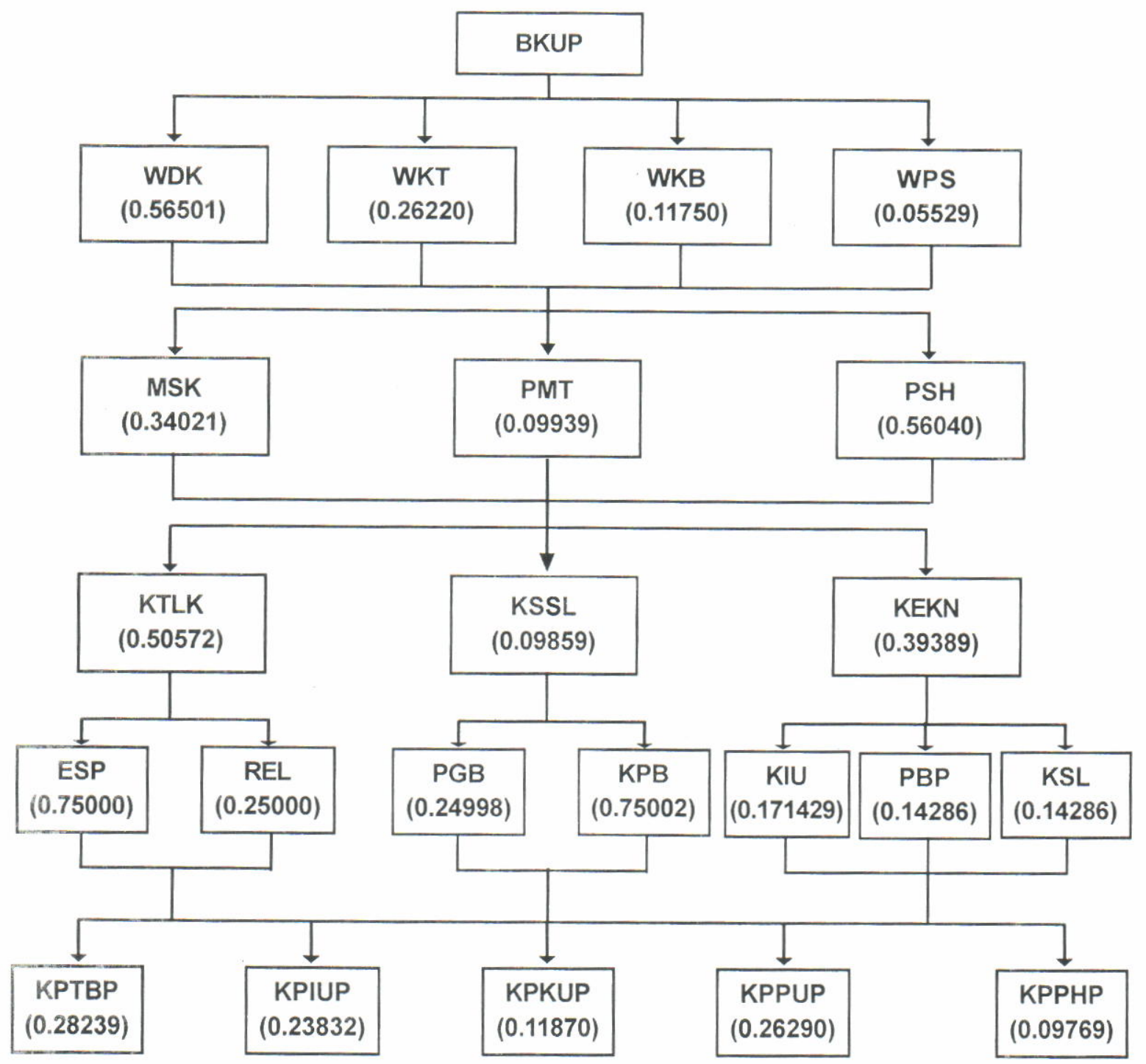

Gambar 4. Struktur hierarki biaya pengembangan kolong untuk budidaya perikanan.

Figure 4. Hierarchy structure of cost from kolong development for fish culture.

Keterangan: Angka dalam kurung merupakan bobot penilaian reponden dari hasil pengolahan data primer menggunakan AHP

Remaks: Value in parenthesis as a weight of respondent judgement from result primary data calcutation Using AHP

Keterangan/Remaks:

BKUP = biaya/kerugian kolong untuk pengembangan budidaya perikanan /benefit of "kolong" for fisheries culture development

WDK = wilayah desa di mana kolong berada/rural area where "kolong" exiting 


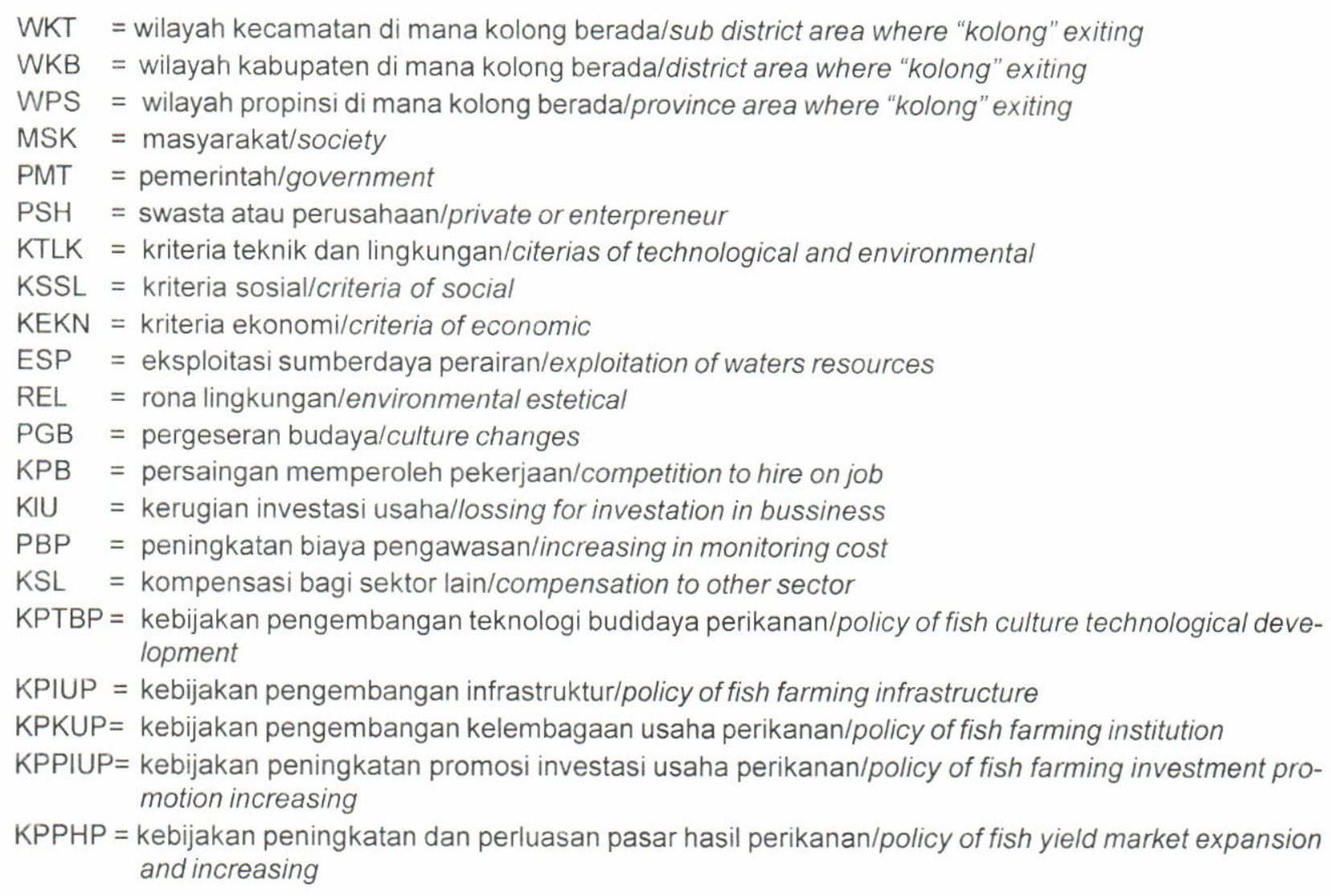

pengembangan budidaya perikanan pada lahan bekas galian tambang timah di Propinsi Kepulauan Bangka Belitung mendatangkan biaya/kerugian yang lebih banyak dirasakan oleh wilayah di tingkat wilayah desa (WDK) dengan bobot 0.56501 , selanjutnya tingkat wilayah kecamatan (WKT) dengan bobot 0.26220 , wilayah kabupaten (WKB) dengan bobot 0.11750 , dan terakhir pada tingkat wilyah propinsi (WPS) dengan bobot 0.05529 .

Biaya yang ditimbulkan dari pengembangan budidaya perikanan pada lahan bekas galian tambang tersebut lebih banyak dirasakan oleh pengusaha (PSH) dengan bobot 0.56040 dibanding dengan masyarakat (MSK) dengan bobot 0.34021 dan pemerintah (PMT) dengan bobot 0.09939. Biaya yang akan diterima bila dilakukan usaha budidaya perikanan di lahan tersebut, ternyata lebih banyak berasal dari biaya/ kerugian pada kriteria teknik dan lingkungan (KTLK) dengan bobot 0.50752 , selanjutnya disusul dengan kriteria ekonomi (KEKN) dengan bobot 0.39389 terkahir dari kriteria sosial (KSSL) dengan bobot 0.09859. Mengingat bahwa usaha budidaya perikanan di lahan bekas galian tambang timah yang tergolong baru dengan menggunakan teknik budidaya intensif, tentunya akan berpotensi pada besarnya resiko kegagalan usaha. Dari sisi biaya, resiko kegagalan tersebut secara teoritis akan lebih banyak dirasakan oleh pengusaha sebagai investor.

Berdasarkan pendapat para responden, alternatif kebijakan yang diprioritaskan untuk mengatasi kerugian yang mungkin akan timbul dari pengembangan usaha budidaya perikanan di lahan kolong adalah kebijakan pengembangan teknologi usaha perikanan (KPTBP) dengan bobot 0.28239 . Berikutnya, secara berturut-turut disusul perioritas kebijakan untuk mengatasi biaya tersebut adalah kebijakan peningkatan promosi investasi usaha budidaya perikanan (KPPUP) dengan bobot 0.26290; kebijakan peningkatan infrastruktur usaha perikanan (KPIUP) dengan bobot 0.23832; kebijakan pengembangan kelembagaan usaha perikanan (KPKUP) dengan bobot 0.11870; dan kebijakan peningkatan dan perluasan pasar hasil perikanan (KPPHP) dengan bobot 0.09769 .

\section{Analisis Ratio Manfaat Biaya pada Pengembangan Usaha}

\section{Budidaya perikanan di lahan bekas galian tambang timah}

Hasil analisis ratio manfaat biaya dari kelima alternatif kebijakan yang ditawarkan ditampilkan pada 
Tabel 5. Hasil analisis biaya pengembangan usaha budidaya perikanan pada lahan bekas galian tambang timah di Propinsi Kepulauan Bangka Belitung

Table 5. Result of analysis of fish culture farming development cost at receptacle land of tin exploitation in Kepulauan Bangka Belitung Province

\begin{tabular}{|c|c|c|c|c|c|c|c|c|c|c|}
\hline \multirow[t]{2}{*}{ No } & \multirow[t]{2}{*}{$\begin{array}{l}\text { Alternatif kebijakan/ } \\
\text { Policy alternatives }\end{array}$} & \multicolumn{2}{|c|}{$\begin{array}{c}\text { Teknik dan } \\
\text { lingkungan/ } \\
\text { Technical and } \\
\text { environmental }\end{array}$} & \multicolumn{2}{|c|}{ Sosial/Social } & \multicolumn{3}{|c|}{ Ekonomi/Economic } & \multicolumn{2}{|c|}{$\begin{array}{c}\text { Rataan/ Prioritas } \\
\text { Average /Priority }\end{array}$} \\
\hline & & ESP & REL & PGB & KPB & KJU & PBP & KSL & Bobot/ & Weight \\
\hline 1 & $\begin{array}{l}\text { Kebijakan } \\
\text { Pengembangan } \\
\text { Teknologi Budidaya } \\
\text { Perikanan/Policy of } \\
\text { Fish Culture } \\
\text { Technological } \\
\text { Development (KPTBP) }\end{array}$ & 0.53196 & 0.29103 & 0.16359 & 0.10877 & 0.49120 & 0.15855 & 0.23160 & 0.28239 & 1 \\
\hline 2 & $\begin{array}{l}\text { Kebijakan } \\
\text { Pengembangan } \\
\text { Infrastruktur Usaha } \\
\text { Perikanan/ Policy of } \\
\text { Fish Farming } \\
\text { Infrastucture } \\
\text { Development (KPIUP) }\end{array}$ & 0.11950 & 0.14839 & 0.38128 & 0.05350 & 0.07614 & 0.40635 & 0.48310 & 0.23832 & 3 \\
\hline 3 & $\begin{array}{l}\text { Kebijakan } \\
\text { Pengembangan } \\
\text { Kelembagaan Usaha } \\
\text { Perikanan/Policy of } \\
\text { Fish Farming } \\
\text { Institutional } \\
\text { Development (KPKUP) }\end{array}$ & 0.05684 & 0.06147 & 0.06637 & 0.24015 & 0.18560 & 0.08117 & 0.13933 & 0.11870 & 4 \\
\hline 4 & $\begin{array}{l}\text { Kebijakan Peningkatan } \\
\text { Promosi Investasi } \\
\text { Usaha } \\
\text { Perikanan/Policy of } \\
\text { Fish Farming } \\
\text { Investment Promotion } \\
\text { Increasing (KPPIUP) }\end{array}$ & 0.23487 & 0.42693 & 0.31987 & 0.47659 & 0.04545 & 0.27968 & 0.05692 & 0.26290 & 2 \\
\hline 5 & $\begin{array}{l}\text { Kebijakan Peningkatan } \\
\text { dan Perluasan Pasar } \\
\text { Hasil Perikanan/Policy } \\
\text { of Fish Yield Market } \\
\text { Expansion and } \\
\text { Increasing (KPPHP) }\end{array}$ & 0.05684 & 0.07218 & 0.06889 & 0.12099 & 0.20161 & 0.07424 & 0.08905 & 0.09769 & 5 \\
\hline
\end{tabular}

Sumber/Resources: Hasil pengolahan data primer menggunakan Analytic Hierarchy Process/Result of calculation from primery data using Analytic Hierarchy Process

Keterangan/Remaks:

$\mathrm{ESP}=$ eksploitasi sumberdaya perairan/exploitation of waters resources

$\mathrm{REL}=$ rona lingkungan/enviromental estetical

$\mathrm{PGB}=$ pergeseran budaya/culture changes

$\mathrm{KPB}=$ persaingan memperoleh pekerjaan/competition to hire on job

$\mathrm{KIU}=$ kerugian investasi usahallossing for investation in bussiness

$\mathrm{PBP}=$ peningkatan biaya pengawasan/increasing in monitoring cost

$\mathrm{KSL}$. = kompensasi bagi sektor lain/compansation to other sector 
Tabel 6. Dari Tabel6, hasil analisis ratio manfaat/biaya untuk pengembangan usaha budidaya perikanan di lahan bekas galian tambang timah diketahui terdapat dua alternatif kebijakan yang layak (nilai ratio $B / C$ > 1) untuk dikembangkan, yaitu kebijakan pengembangan kelembagaan usaha perikanan (KPKUP) dengan nilai rasio sebesar 3,395 dan kebijakan peningkatan dan perluasan pasar hasil perikanan (KPPHP) dengan nilai rasio sebesar 2,920. Tiga alternatif kebijakan lainnya dinilai tidak layak untuk dikembangkan karena memiliki nilai ratio $\mathrm{B} / \mathrm{C}$ $<1$. Ketiga kebijakan tersebut adalah kebijakan peningkatan promosi investasi usaha perikanan (KPPIP) dengan nilai rasio sebesar 0,588 , kebijakan pengembangan teknologi budidaya perikanan (KPTBP) dengan nilai rasio sebesar 0,369 dan kebijakan pengembangan infrastruktur usaha perikanan (KPIUP) dengan nilai rasio sebesar 0,222.

\section{KESIMPULAN DAN IMPLIKASI KEBIJAKAN}

\section{Kesimpulan}

Alternatif kebijakan yang layak untuk dikembangkan dalam rangka pengembangan usaha budidaya perikanan pada lahan bekas galian tambang timah di Propinsi Kepulauan Bangka Belitung adalah kebijakan pengembangan kelembagaan usaha perikanan (KPKUP) dan kebijakan peningkatan dan perluasan pasar hasil perikanan (KPPHP). Pengembangan kedua kebijakan tersebut harus memberikan manfaat kepada para pelaku ekonomi, yaitu masyarakat, pengusaha dan pemerintah. Bentuk manfaat yang terbesar dapat dirasakan oleh para pelaku ekonomi tersebut adalah berupa transfer teknologi budidaya perikanan, kebanggaan dan pendapatan daerah.

\section{Implikasi Kebijakan}

Lahan konversi bekas galian tambang yang banyak terdapat di Propinsi Kepulauan Bangka Belitung dapat dipandang sebagai potensi sumberdaya perairan yang bermanfaat bagi peningkatan kesejahteraan masyarakat. Salah satu bentuk upaya pemanfaatan perairan di lahan bekas galian tambang timah tersebut adalah melalui upaya pengembangan usaha budidaya daya perikanan dengan sistem karamba jaring apung (KJA). Secara empiris, pengembangan usaha budidaya perikanan di lahan bekas galian tambang timah tersebut dapat memberikan tingkat keuntungan

Tabel6. Rasio manfaat biaya pengembangan usaha perikanan pada lahan bekas galian tambang timah di Propinsi Kepulauan Bangka Belitung

Table 6. Ratio of benefit cost of fish culture farming development cost at receptacle land of tin exploitation in Kepulauan Bangka Belitung

\begin{tabular}{llcccc}
\hline No & Alternatif kebijakan/Policy alternative & $\begin{array}{c}\text { Manfaat/ } \\
\text { Benefit } \\
\text { (B) }\end{array}$ & $\begin{array}{c}\text { Biaya/ } \\
\text { Cost } \\
\text { (C) }\end{array}$ & B/C ratio & $\begin{array}{c}\text { Prioritas/ } \\
\text { Priority }\end{array}$ \\
\hline $1 \quad \begin{array}{l}\text { Kebijakan Pengembangan Teknologi Budidaya } \\
\text { Perikanan/Policy of Fish Culture }\end{array}$ & 0.10416 & 0.28239 & 0.36887 & 4 \\
$\quad \begin{array}{l}\text { Technological Development (KPTBP) } \\
\text { Kebijakan Pengembangan Infrastruktur Usaha } \\
\text { Perikanan/Policy of Fish Farming } \\
\text { Infrastucture Development (KPIUP) }\end{array}$ & 0.05293 & 0.23832 & 0.22211 & 5 \\
$3 \begin{array}{l}\text { Kebijakan Pengembangan Kelembagaan } \\
\text { Usaha Perikanan/Policy of Fish Farming } \\
\text { Institutional Development (KPKUP) }\end{array}$ & 0.40301 & 0.1187 & 3.39506 & 1 \\
$4 \begin{array}{l}\text { Kebijakan Peningkatan Promosi Investasi } \\
\text { Usaha Perikanan/Policy of Fish Farming } \\
\text { Investment Promotion Increasing (KPPIUP) }\end{array}$ & 0.15462 & 0.2629 & 0.58811 & 3 \\
\hline $\begin{array}{l}\text { Kebijakan Peningkatan dan Perluasan Pasar } \\
\text { Hasil Perikanan/Policy of Fish Yield Market } \\
\text { Expantion and Increasing (KPPHP) }\end{array}$ & 0.28528 & 0.09769 & 2.92037 & 2 \\
\hline
\end{tabular}

Sumber/Sources: Hasil pengolahan data primer menggunakan Analytic Hierarchy Process/Result of cal culation from primary data using Analytic Hierarchy Process 
yang cukup signifikan sehingga dipandang layak. Hal ini terlihat dari hasil perhitungan analisis ratio penerimaan biaya (R/C) pada usaha tersebut yang menunjukkan nilai lebih besar dari satu.

Peran pemerintah sangat diperlukan bagi upaya mewujudkan nilai tambah (value added) lahan bekas galian tambang timah untuk usaha budidaya perikanan yang dapat dilakukan melalui penerapan perangkat kebijakan yang dapat menciptakan kondisi yang bergairah bagi pengambangan usaha tersebut. Untuk itu, sebaiknya penerapan perangkat kebijakan tersebut merupakan pengembangan dari kebijakan pengembangan kelembagaan usaha perikanan; dan kebijakan peningkatan dan perluasan pasar hasil perikanan. Selain itu, dengan mempertimbangkan kemungkinan untuk mensinergiskan kedua kebijakan tersebut dalam satu paket kebijakan, diharapkan dapat diperoleh akselerasi capaian tujuan dan keberlanjutan (sustainability) usaha budidaya perikanan pada lahan bekas galian tambang timah di Propinsi Kepulauan Bangka Belitung.

Namun demikian, hasil analisis kebijakan ini masih belum memuaskan karena belum mampu menentukan strategi implementasi dari kedua kebijakan yang dinilai layak di atas. Selain itu, penelitian ini belum dapat mengidentifikasi langkah-langkah tindak lanjut yang dianggap efektif bagi pengembangan usaha budidaya perikanan pada lahan bekas galian tambang timah tersebut.

\section{DAFTAR PUSTAKA}

Dinas Perikanan dan Kelautan Propinsi Kepulauan Bangka Belitung. 2003. Data Statistik Perikanan Propinsi Kepulauan Bangka Belitung Tahun 2003. Dinas Perikanan dan Kelautan Propinsi Kepulauan Bangka Belitung. $231 \mathrm{pp}$

Juhar, R. 2000. Alternatif Pemanfaatan Kolong dan Lahan Kritis Secara Terpadu. STANNIA Edisi Februari 2000. PT. Timah. Bangka. p. $24-29$.
Mustafa, A., J. Haluan dan Wiryawan, B. 2003. Analisis Rencana Startegis Pengelolaan Sumberdaya Perikanan Pantai Provinsi Lampung. Jurnal Pesisir dan Lautan. Volume 5. No. 1. 2003. PKSPL-IPB. Bogor. p. 15-24

Permadi S. B. 1992. Analytic Hierarchy Process (AHP). Departemen Pendidikan dan Kebudayaan, Pusat Antar Universitas- Studi Ekonomi, Universitas Indonesia. Jakarta. $163 \mathrm{pp}$.

Pusat Kajian Sumberdaya Pesisir dan Luatan (PKSPL). 2002. Studi Identifikasi Potensi dan Pengembangan Kelautan dan Perikanan Propinsi Kepulauan Bangka Belitung. Laporan Akhir Kerjasama Dinas Kelautan dan Perikanan Propinsi Kepulauan Bangka Belitung dan Pusat Kajian Sumberdaya dan Lautan - Institut Pertanian Bogor. 253 pp.

Rifqi, M., Bengen, D.G. dan Nikijuluw, V.P.H. 2003. Analisis Kebijakan Pengembangan Perikanan Wilayah Pesisir Kabupaten Padang Pariaman. Jurnal Pesisir dan Lautan. Volume 5. No. 1. 2003. PKSPL-IPB. Bogor. p. 48-66.

Saaty, T.L. 1999. Decision Making for Leader: The Analytic Hierarchy Process for Decision in A Complex World. 1999/2000 Edition. University of Pittsburgh, Pittsburgh, 322 Mervis Hall. 315 pp.

Saaty, R.W. and Saaty, T.L. 2003. Decison Making in Complex Enviroments: The Analytic Hierarchy Process (AHP) for Decision Making and The Analitic Network Process (ANP) for Decision Making with Dependence and Feedback. Katz Graduate School of Business, University of Pittsburgh, Pittsburg, email: saaty@katz.pitt.edu. 114 pp.

Tomboelu, N., D.G. Bengen., Nikijuluw, V.P.H. dan Idris, I. 2000. Analisis Kebijakan Pengelolaan Sumberdaya Terumbu Karang di Kawasan Bunaken dan Sekitarnya. Jurnal Pesisir dan Lautan. Volume 3. No. 1. 2003. PKSPL-IPB. Bogor. p. 51-67.

Wardoyo, S.E., Prihadi, T.H., Pratiwi, E., Praseno, O. dan Sulhi, M. 2003. Riset Pengembangan Budidaya Budidaya Ikan di Genangan Bekas Galian Pasir di Bantaran Sungai Citarum, Jawa Barat. Laporan Teknis Proyek Pusat Riset Perikanan Budidaya. Jakarta. Tidak dipublikasi. 